\title{
PEMANFAATAN MEDIA MASSA OLEH PENEGAK HUKUM DALAM PENANGGULANGAN TINDAK PIDANA KORUPSI
}

\author{
Budiyono \\ Fakultas Hukum Universitas Jenderal Soedirman Purwokerto \\ e-mail: budiyono_elkam@yahoo.co.id
}

\begin{abstract}
ABSTRAK
Seiring dengan menguatnya isu korupsi, berbagai upaya atau langkah telah dilakukan pemerintah baik dari aspek substantif peraturan perundang-undangan korupsi, aspek struktur institusi penegak hukum yang melakukan pemberantasan korupsi maupun dari aspek kultur masyarakat yang dibangun dalam rangka menanamkan nilai-nilai anti korupsi. Berbagai upaya pembaharuan produk hukum dalam rangka penanggulangan atau pemberantasan tindak pidana korupsi tersebut belum juga menunjukkan hasil yang maksimal. Dewasa ini kian banyak elit politik yang terjerat kasus korupsi. Melihat fenomena di atas tampak adanya keterbatasan kemampuan hukum pidana untuk penanggulangan dan pemberantasan tindak pidana korupsi. Untuk itu diperlukan sarana lain (non-penal) selain sarana pidana (penal) dalam penanggulangan dan pemberantasan tindak pidana korupsi.
\end{abstract}

Kata Kunci: korupsi, penal, non-penal.

\begin{abstract}
Along with the continuously rising of the corruption issue, various actions or steps has been taken by the government whether from the corruption aspect of substantive aspects, aspects of the structure of corruption eradication and cultural aspects of the community that was built in order to inculcate the values of anti-corruption. Various efforts to reform the legal product in order to control or perform an eradication of corruption, but it was not showing the maximum results. Today, a large number of political elites are entangled in corruption cases. This phenomenon shows an appearance of the limited ability of the law to prevent and eradicate the corruption. Thats why it required another means (non-penal) besides the criminal (penal) means, in the prevention of corruption.
\end{abstract}

Keywords: corruption, penal, non penal.

\section{PENDAHULUAN}

Bergulirnya reformasi yang mana juga disertai dengan menguatnya tuntutan akan supremasi hukum mengharuskan pihak aparatur pemerintahan bangsa Indonesia khususnya lembaga yudikatif bekerja ekstra untuk memenuhi tuntutan tersebut. Salah satu tuntutan masyarakat dalam agenda supremasi hukum adalah pemberantasan korupsi. Karena korupsi yang ditemani oleh kolusi dan nepotisme sebagai suatu biangkerok terjadinya krisis multidimensi yang melanda bangsa Indonesia. Dari sudut pandang hak asasi manusia, tindak pidana korupsi yang meluas dan sistematis juga merupakan pelanggaran terhadap hak-hak sosial dan hak-hak ekonomi masyarakat, maka tindak pidana korupsi tidak lagi dapat digolongkan sebagai tindak ordinary crime melainkan telah menjadi suatu tindak pidana luar biasa atau extra ordinary crime.

Seiring dengan menguatnya isu korupsi, berbagai upaya atau langkah telah dilakukan pemerintah baik dari aspek substantif peraturan perundang-undangan korupsi, aspek struktur institusi dari penegak hukum yang melakukan pemberantasan korupsi maupun dari aspek kultur masyarakat yang dibangun dalam rangka menanamkan nilai-nilai anti korupsi. Namun demikian upaya pemerintah ini sekalipun belum maksimal paling tidak telah menunjukan itikad keseriusan dalam memerangi tindak pidana korupsi. Hal ini terbukti dengan adanya berbagai kalangan dan tokoh baik eksekutif, legislatif, maupun yudikatif yang harus mendekam di balik tembok penjara karena melakukan tindakan korupsi.

Semangat pemberantasan korupsi yang diawali dengan perubahan dan pembaharuan hukum tentang korupsi yaitu dengan telah diundangkannya UndangUndang No. 28 Tahun 1999 tentang Penyelenggaraan Negara yang Bersih dan Bebas dari Korupsi Kolusi Nepotisme, Undang-Undang No. 31 Tahun 1999 
yang dirubah lagi Undang-Undang No. 20 tahun 2001 mengenai Pemberantasan akan Tindak Pidana Korupsi. Selain perangkat hukum, pemerintah juga telah membentuk TIMTAS-TIPIKOR dan Komisi Pemberantasan Tindak Pidana Korupsi (KPK) yang ditetapkan di dalam Undang-Undang No. 30 Tahun 2002, Undang-Undang No. 46 Tahun 2009 tentang Pengadilan Tindak Pidana Korupsi.

Berbagai upaya di dalam rangka pembaharuan suatu produk hukum dalam rangka penanggulangan atau pemberantasan tindak pidana korupsi tersebut belum juga menunjukkan hasil yang maksimal. Hal ini pernah pula dikemukakan oleh Andi Hamzah bahwa korupsi tetap merajalela, buktinya peraturanperaturan silih berganti, selalu yang belakangan itu memperbaiki yang duluan, namun korupsi dalam segala bentuknya dirasakan masih juga mengganas serta masih merajalela. Perangkat substansi hukum yang diperankan oleh criminal justice system (SPP), tidak dapat menyentuh semua pelaku tindak pidana korupsi yang ada di Indonesia (Andi Hamzah, 1991: 3). Kalau toh sudah ada atau banyak pelaku yang dijatuhi dengan pidana, itu merupakan potret kecil dari fenomena yang sesungguhnya.

Melihat fenomena di atas tampaklah akan adanya suatu keterbatasan kemampuan hukum pidana untuk penanggulangan dan pemberantasan tindak pidana korupsi. Untuk itu diperlukan sarana lain (non-penal) selain sarana pidana (penal) dalam penanggulangan dan pemberantasan tindak pidana korupsi. Perlunya di intensipkan dan diepektipkan sarana non-penal untuk penanggulangan kejahatan (termasuk korupsi) menurut Barda Nawawi Arief, antara lain karena adanya alasan bahwa masih diragukannya ataupun dipermasalahkannya efektivitas sarana penal dalam mencapai tujuan politik kriminal (Barda Nawawi Arief, 1996:58).

Untuk mengimbangi kekurangan dan keterbatasan sarana penal tersebut, maka salah satu upaya nonpenal yang penting pula untuk dimanfaatkan dalam penegakan hukum pidana korupsi adalah melalui pemanfaatan media pers atau juga media massa. Hal ini sebagaimana disampaikan oleh Barda Nawawi Arief, bahwa di samping upaya-upaya non-penal dapat ditempuh dengan menyehatkan masyarakat lewat kebijakan sosial dan dengan menggali berbagai potensi yang ada di dalam masyarakat itu sendiri, dapat pula upaya non-penal itu digali dari berbagai sumber lainnya yang juga mempunyai potensi efekpreventif. Sumber lain itu misalnya media pers atau media massa, pemanfaatan akan kemajuan teknologi (yang mana dikenal dengan istilah techno-prevention) dan pemanfaatan potensi efek preventif dari aparat penegak hukum (Barda Nawawi Arief, 1996:58).

Dari pernyataan Barda Nawawi Arief tersebut jelaslah bahwasanya salah satu upaya non-penal yang mana mempunyai potensi efek preventif dalam penanggulangan kejahatan itu adalah media massa. Sehingga apabila media massa dimanfaatkan dalam penanggulangan tindak pidana korupsi di Indonesia adalah sudah sesuai dengan kerangka teoritis dalam kebijakan kriminal.

Pentingnya media massa dimanfaatkan dalam upaya penanggulangan tindak pidana korupsi karena media massa atau pers mempunyai fungsi yang cukup strategis dalam politik kriminal, seperti dikemukakan oleh G.P. Hoefnagels bahwa media massa atau mass media ini sebagai salah satu unsur dari politik kriminal atau criminal policy (Hoefnagels G. Peter, 1969:56). Fungsi media massa dalam kerangka politik kriminal menurut Hoefnagels ditujukan untuk mempengaruhi pandangan-pandangan masyarakat tentang tindak pidana dan pemidanaan atau influencing view of society on crime and punishment. Peranan media massa dalam kerangka politik kriminal ini menurut Hoefnagels disejajarkan dengan upaya-upaya politik kriminal yang lain yaitu Criminal Law Application (Practical Criminology) yaitu penanggulangan tindak pidana dengan sarana hukum pidana dan Prevention Without Punishment yaitu penanggulangan tindak pidana melalui sarana di luar hukum pidana.

Berdasarkan alasan sebagaimana diuraikan di atas, maka dalam penanggulangan tindak pidana korupsi melalui upaya penal atau sistem peradilan pidana, perlu penulis kemukakan bahwa mengingat tindak pidana korupsi di Indonesia sudah merupakan extra ordinary crime atau kejahatan luar biasa, maka sudah merupakan suatu tuntutan supaya pemberantasan tindak pidana korupsi harus dilakukan dengan cara yang luar biasa pula, yakni dengan cara mengadakan prosedur luar biasa, extra-ordinary measures, yang antara lain berupa pemanfaatan media massa dalam aktivitas penegakan hukum pidana dalam rangka pemberantasan tindak pidana korupsi.

Tulisan ini difokuskan terhadap permasalahan pemanfaatan media massa oleh pihak aparat penegak hukum dalam penanggulangan tindak pidana korupsi. Penulis melihat bahwa di dalam penegakan hukum terhadap tindak pidana korupsi yang dikelola oleh sistem peradilan pidana atau disingkat SPP, media massa sangat relevan dimanfaatkan sebagai sarana untuk mempengaruhi pandangan-pandangan akan masyarakat mengenai kejahatan dan pemidanaan atau juga influencing views of society on crime and 
punishment, yaitu kejahatan dan pemidanaan tindak pidana korupsi. Dengan demikian tiap-tiap unsur penegak hukum berkewajiban menjalin kerjasama dengan media massa guna memberikan informasi kepada masyarakat tentang proses penanganan tindak pidana korupsi yang sedang dilakukan dan selanjutnya media massa melakukan kontrol sosial terhadap proses peradilan pidana korupsi yang sedang ditangani oleh aparat penegak hukum pidana (Kepolisian, Kejaksaan, Pengadilan dan Pemasyarakatan).

Untuk memperdalam analisis akan pemanfaatan media massa oleh pihak aparat penegak hukum dalam penanggulangan tindak pidana korupsi, maka terhadap permasalahan pokok di atas, dirumuskan beberapa permasalahan sebagai berikut: Bagaimana fungsi dan peran media massa dalam penanggulangan tindak pidana korupsi; Bagaimana pelaksanaan pemanfaatan media massa oleh pihak penegak hukum (Kepolisian, Kejaksaan, Pengadilan dan Pemasyarakatan) dalam menangani tindak pidana korupsi; Bagaimanakah formulasi dalam regulasi pemanfaatan media massa untuk penanggulangan tindak pidana korupsi.

\section{PEMBAHASAN}

\section{Fungsi dan Peran Media Massa sebagai Kontrol terhadap Sistem Peradilan Pidana}

Media massa adalah suatu jenis komunikasi yang ditujukan kepada sejumlah khalayak yang tersebar, heterogen dan anomim melewati media cetak atau elektronik, sehingga pesan informasi yang sama itu dapat diterima secara serentak dan sesaat (Deddy Mulyana, 2008:17). Pemanfaatan media massa artinya penggunaan berbagai bentuk media massa, baik cetak maupun elektronik untuk tujuan tertentu (Arief A. Mangkoesapoetra, http://www.re-searchengines.com/ mangkoes6-04-2.html diakses 31 Agustus 2010).

Secara umum, media massa mempunyai fungsi sebagai media informasi, pendidikan, hiburan dan kontrol sosial. Hal ini seperti dirumuskan dalam Pasal 3 ayat 1 dan ayat 2 Undang-Undang No. 40 Tahun 1999 tentang Pers, yaitu Fungsi Pers Nasional adalah sebagai media informasi, pendidikan, hiburan dan kontrol sosial, serta dapat berfungsi sebagai lembaga ekonomi.

Fungsi kontrol sosial dari pers tersebut selanjutnya dijelaskan dalam Penjelasan Umum Undang-Undang Pers No. 40 Tahun 1999 tentang Pers, yang antara lain dinyatakan, pers yang mana juga melaksanakan kontrol sosial sangat penting pula untuk mencegah terjadinya penyalahgunaan kekuasaan baik korupsi, kolusi, nepotisme, maupun akan penyelewengan dan penyimpangan lainnya.

Berdasarkan perumusan fungsi pers atau media massa dalam Undang-Undang Pers di atas dapat diketahui bahwa fungsi dari pers atau media massa adalah sebagai media informasi, pendidikan, hiburan dan kontrol sosial. Dalam kaitan hubungannya dengan pemanfaatan media massa dalam penanggulangan tindak pidana korupsi, maka fungsi media massa di sini terutama sebagai media informasi dan kontrol sosial.

Dengan demikian dapat penulis kemukakan bahwa dalam pemanfaatan media massa baik cetak maupun elektronik, kaitannya untuk penanggulangan tindak pidana korupsi antara lain berupa: Informasi atau berita-berita aktual dari berbagai isu yang berkaitan dengan praktik-praktik korupsi; Pengungkapan dan peliputan kasus-kasus korupsi dan modus operandi dari praktik-praktik korupsi; Mengangkat berbagai berita korupsi di berbagai level pemerintahan dan lembaga penegak hukum secara objektif; Pemberitaan penanganan akan tindak pidana korupsi oleh penegak hukum sejak penyidikan, penuntutan, pengadilan dan pemasyarakatan.

Fungsi kontrol sosial media massa terkait dengan penanggulangan tindak pidana korupsi disini antara lain dapat berupa pemantauan terhadap pengungkapan kasus-kasus korupsi yang ditangani oleh penegak hukum yang dimulai sejak penyidikan, penuntutan, pengadilan dan pemasyarakatan.

Peranan pers atau juga media massa sebagaimana dirumuskan dalam Pasal 6 Undang-Undang Pers No. 40 Tahun 1999 tentang Pers disebutkan bahwa Pers Nasional akan melaksanakan peranan sebagai berikut: Untuk memenuhi hak masyarakat untuk mengetahui; Menegakkan nilai-nilai dasar demokrasi, mendorong mewujudkan supremasi hukum, dan Hak Asasi Manusia, serta menghormati kebhinekaan; Mengembangkan pendapat umum yang berdasarkan informasi yang tepat, akurat dan benar; Melakukan pengawasan, kritik, koreksi dan juga saran terhadap hal-hal yang berkaitan dengan kepentingan umum; Memperjuangkan keadilan dan kebenaran.

Melihat peranan yang strategis dari pers atau media massa tersebut, maka G.P. Hoefnagels mencantumkan pers atau media massa (mass media) ini sebagai salah satu unsur yang harus ada dalam kebijakan penanggulangan kejahatan atau juga criminal policy. Seperti digambarkan oleh Hoefnagels pada skema berikut ini: 
Bagan Ruang Lingkup Criminal Policy

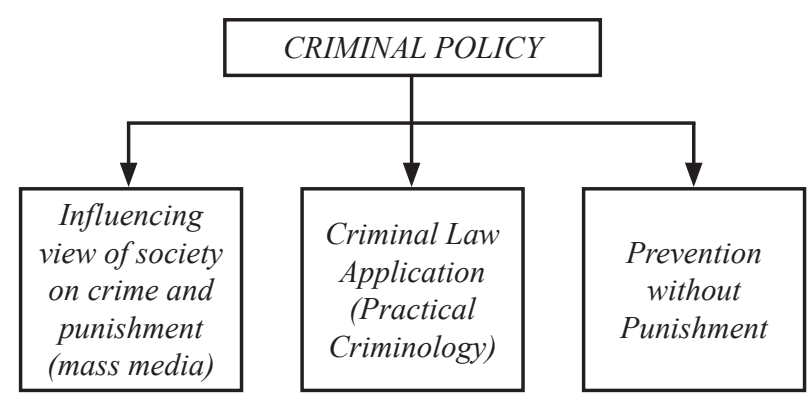

Dari skema di atas dapat diketahui bahwa fungsi dari media massa dalam kerangka politik kriminal menurut Hoefnagels ditujukan untuk mempengaruhi pandangan-pandangan masyarakat tentang kejahatan dan pemidanaan atau influencing view of society on crime and punishment. Peranan media massa dalam kerangka politik kriminal ini menurut Hoefnagels disejajarkan dengan upaya-upaya politik kriminal yang lain yaitu Criminal Law Application (Practical Criminology) yaitu penanggulangan kejahatan dengan sarana hukum pidana dan juga Prevention Without Punishment yaitu penangulangan kejahatan melalui sarana di luar hukum pidana.

Sehubungan dengan pendapat Hoefnagels bahwa fungsi media massa adalah untuk mempengaruhi pandangan-pandangan masyarakat tentang kejahatan dan pemidanaan maka apabila dihubungkan dengan fungsinya dalam hal penanggulangan tindak pidana korupsi, media massa di sini diharapkan dapat untuk berpengaruh terhadap pandangan masyarakat tentang pengetahuan, perasaan atau keyakinan dan perilaku partisipatif masyarakat dalam penanggulangan tindak pidana korupsi.

Media massa sebagai suatu sarana yang bersifat non-penal dapat diperankan juga sebagai salah satu upaya penanggulangan tindak pidana korupsi. Sebagai sarana non-penal media massa dapat pula digunakan sebagai pendorong bekerjanya sarana penal agar menjadi lebih efektif.

Peranan media massa di dalam menyampaikan informasi kepada masyarakat tentang penanganan penegakan hukum tindak pidana korupsi, agar dapat diketahui secara cepat oleh masyarakat, tidak perlu dilakukan dengan komunikasi tatap muka. Dalam hal ini aparat penegak hukum (Kepolisian, Kejaksaan, Pengadilan, Lembaga Pemasyarakatan) cukup untuk melakukan press release ke media atau mengundang wartawan untuk jumpa pers, sehingga dalam waktu singkat informasi itu akan tersebar luas ke tengah masyarakat.

Dilihat dari dimensi media massa, maka informasi yang disampaikan oleh aparat sistem peradilan pidana
(SPP) mengenai materi penanganan kasus korupsi yang diterima masyarakat ini diharapkan mempunyai efek yang positif dalam penanggulangan tindak pidana korupsi.

Efek atas adanya pemberitaan akan penanganan tindak pidana korupsi yang disampaikan oleh aparat sistem peradilan pidana ini yaitu dengan adanya efek kognitif, afektif, dan konatif. Efek kognitif meliputi peningkatan akan kesadaran, belajar, dan tambahan pengetahuan. Efek afektif itu berhubungan dengan emosi, perasaan, dan attitude atau sikap. Sedangkan efek konatif berhubungan dengan perilaku dan niat untuk dapat melakukan sesuatu menurut cara tertentu (www.subscrib.com, diakses 9 Oktober 2010).

Media massa sebagai kekuatan strategis dalam menyebarkan informasi itu merupakan salah satu otoritas sosial yang berpengaruh dalam membentuk sikap dan norma sosial daripada suatu masyarakat. Pengaruh media massa terhadap perilaku dan sikap masyarakat, dipelopori oleh DeFleur yang selalu mengembangkan teori tentang efek. Pengembangan awal yang telah dilakukan oleh DeFleur adalah dengan memperhitungkan variabel psikologis dalam proses efek, maka selanjutnya dia mengembangkan teorinya dengan memasukan variabel norma budaya kedalam efek dari media massa. Teori yang disebut Cultural Norms ini beranggapan bahwa media tidak hanya memiliki efek langsung terhadap individu, tetapi juga mempengaruhi kultur, pengetahuan kolektif dan juga norma serta nilai-nilai dari suatu masyarakat. Media massa telah dapat menghadirkan seperangkat citra atau images, gagasan dan evaluasi dari mana khalayak dapat memilih dan juga menjadikan acuan bagi perilakunya. Misalnya saja dalam hal perilaku pemberian hadiah kepada parpejabat, med ia massa memberikan suatu pandangan komulatif mengenai apa yang dianggap normal atau juga wajar dan yang tidak wajar (www.subscrib.com, diakses 9/10/10).

Dalam harian Suara Merdeka yang berjudul Media Berperan Sentral Ciptakan Pencitraan dinyatakan bahwa opini publik yang terbangun oleh wartawan melalui media massa dinilai memiliki peran sentral dalam menentukan baik-buruknya seseorang atau lembaga. Namun sebaliknya, wartawan juga sangat berperan dalam hal menciptakan pencitraan (Suara Merdeka, Edisi Rabu 13 Januari 2010:12).

Ketua DPRD Jateng Murdoko menyatakan sejak tahun 1999 citra legislatif sangat terpuruk. Kesan korupsi sangatlah melekat di lembaga wakil rakyat tersebut. Tapi saat ini kinerja Dewan sudah mulai membaik, itu pun tidak akan ada artinya apabila keluarnya di media itu tidak sesuai, disinilah peran 
wartawan sangat dibutuhkan (Suara Merdeka, Edisi Rabu 13 Januari 2010:12).

Dinyatakan pula oleh Wakil Ketua DPRD Jateng, Abdul Fikri Fakih, wartawan jauh lebih powerfull dibanding legislatif. Sebab, pemberitaan wartawan akan mempengaruhi kebijakan pemerintah. Contoh tim mafia hukum yang dibentuk presiden, tak akan ada apa-apanya saat sidak ke kamar tahanan kalau tidak diblow up oleh media (Suara Merdeka, Edisi Rabu 13 Januari 2010:12).

Di dalam Seminar Jurnalis dengan tema Peran Pers dalam Pemberantasan Korupsi, yang diadakan Lembaga Pers Mahasiswa (LPM) Agrica Fakultas Peternakan Unsoed, Auditorium Fakultas Peternakan Unsoed, Purwokerto, Sabtu tanggal 11 Desember 2010, Anggota Divisi Humas Komisi Pemberantasan Korupsi (KPK), Irsyad Prakasa, menyatakan bahwa berdasarkan survei Goverment Assesment Survei PSKK UGM dan juga Kemitraan tahun 2006 tentang tingkat keseriusan lembaga dalam pemberantasan korupsi, media massa menempati urutan pertama yakni 45,61\%. Jumlah itu jauh melampaui lembaga lain seperti LSM, Kepala Daerah, DPRD, Kejaksaan, dan Kepolisian. Bahkan kepolisian sebagai lembaga penegak hukum di negeri ini menempati urutan paling akhir dalam survei tersebut, yakni 22,13\%. Sedangkan peran media massa dalam kaitannya dengan KPK yakni berfungsi sebagai media informasi yang objektif dan berimbang, media pendidikan di dalam proses pembentukan karakter bangsa, dan sebagai media pengawas yang mengontrol pelaksanaan tupokasi aparat, pejabat, elit politik dan penyelenggara negara (Suara Merdeka, Edisi Rabu 13 Januari 2010:12).

Peran media massa dalam pemberantasan korupsi antara lain dikemukakan pula oleh anggota Divisi Investigasi Indonesian Corruption Watch (ICW), Tema S. Langkun, menjelaskan media memiliki tiga peran serta yang vital dalam pemberantasan korupsi yaitu mengungkap kasus korupsi melalui pemberitaan, melakukan investigasi terhadap kasus korupsi dan melakukan kontrol dan pengawasan terhadap sebuah isu tindak pidana korupsi (Suara Merdeka, Edisi Rabu 13 Januari 2010:12).

Dari beberapa pendapat tersebut di atas diketahui bahwa media massa mempunyai peranserta yang vital dan strategis dalam penanggulangan tindak pidana korupsi, karena media massa dapat mengungkap kasus korupsi melalui pemberitaan dan melakukan kontrol atau pengawasan terhadap berjalannya pengungkapan kasus korupsi oleh penegak hukum.

Kontrol yang dilakukan oleh media massa terhadap aparat penegak hukum (sistem peradilan pidana) yaitu dengan cara meliput atau memberitakan proses pelaksanaan penanganan dan penanggulangan tindak pidana korupsi. Materi yang diliput atau diberitakan ini akan sekaligus mempunyai fungsi dan juga peran yang strategis dalam politik kriminal atau criminal policy, khususnya penanggulangan kejahatan (tindak pidana korupsi) melalui sarana non-penal. Disini penulis melihat bahwa materi atau isi pemberitaan media massa merupakan salah satu bentuk dari upaya non-penal untuk menanggulangi kejahatan. Perlunya dilakukan upaya non-penal ini karena adanya alasan bahwa masih diragukannya atau dipermasalahkannya efektivitas sarana penal dalam mencapai tujuan politik kriminal (Barda Nawawi Arief, 1996:58).

Dilihat dari suatu dinamika agenda, maka tampak diketahui bahwa pemanfaatan media massa untuk penanggulangan tindak pidana korupsi, sekaligus merefleksikan adanya interaksi di antara agenda media, agenda pengambil kebijakan, dan agenda publik. Adanya interkasi ini terlihat dengan adanya pertanggungjawaban pers atas pemberitaan yang mana menyangkut dengan masyarakat tidak akan dapat dilepaskan keterkaitannya dengan interaksi antara pers dengan pemerintah. Menurut Samsul Wahidin, dengan asumsi pemerintah sebagai instansi yang juga berkedudukan sebagai pembina kehidupan pers besar pengaruhnya terhadap corak kehidupan pers di negara bersangkutan. Bahkan dalam sistem pers di Indonesia sering dikemukakan hubungan itu juga tidak terlepas dengan masyarakat sebagai bagian dari interaksi yang dituangkan dalam cita-cita terwujudnya interaksi antara pemerintah, pers dan masyarakat (Samsul Wahidin, 2006:100-101).

Dalam penanggulangan tindak pidana korupsi, dinamika agenda dari ketiga sub-sistem (Pemerintah, Media, Masyarakat) proses interakasi yang diperankan masing-masing berkedudukan sejajar, yaitu adanya keinginan bersama untuk dapat menanggulangi tindak pidana korupsi. Pemerintah yang dijalankan oleh aparat sistem peradilan pidana, media, dan masyarakat mempunyai keinginan kuat untuk memberantas atau menanggulangi tindak pidana korupsi.

Landasan pokok yang mana harus dipergunakan dalam interkasi ini adalah kepercayaan atau saling percaya antara pihak pers dengan pemerintah (sistem peradilan pidana) secara timbal balik khususnya yang datang dari pemerintah. Atas dasar kepercayaan ini, yang disajikan oleh pres tidak dilihat dalam perspektif negatif tetapi secara proporsional mengedepankan pula aspek positifnya (Samsul Wahidin, 2006:103).

Berdasarkan pada landasan pokok di atas, maka hendaknya reaksi aparat sistem peradilan pidana 
dalam menanggapi materi pemberitaan media massa mengenai penanganan tindak pidana korupsi tidak perlu ditanggapi secara reaktif negatif, melainkan harus dilihat sebagai bentuk positif bahwa kinerja atau kerjanya terpantau publik melalui media massa.

Di sini media bukan saja sebagai sumber informasi publik, melainkan juga sebagai faktor pendorong atau trigger untuk dapat mengoptimalkan fungsi dan peran instansi penegak hukum (sistem peradilan pidana) dalam penanggulangan tindak pidana korupsi.

Faktor pendorong ini didukung oleh kelebihan media massa itu sendiri yaitu Pertama, media massa mempunyai daya jangkau yang luas. Pemberitaan akan penegakkan hukum melalui media massa akan mempunyai daya jangkau atau coverage yang sangat luas dalam menyebarluaskan informasi penanganan tindak pidana korupsi, akan mampu untuk melewati batas wilayah (geografis), kelompok umur, jenis kelamin dan juga sosial-ekonomi-status (demografis) dan perbedaan paham dan juga orientasi psikografis. Dengan begitu, akan menghasilkan umpan balik bagi aparat penegak hukum, pelaku tindak pidana korupsi maupun keluarganya. Bagi aparat penegak hukum melahirkan dampak psikologis yaitu dari bekerjanya terpantau oleh publik. Bagi terdakwa tindak pidana korupsi atau keluarganya akan menimbulkan efek malu, karena kejahatannya diketahui oleh publik. Kedua, kemampuannya melipat-gandakan pesan atau multiplier of message yang luar biasa. Suatu peristiwa hukum bisa dilipatgandakan pemberitaannya sesuai jumlah eksemplar koran, tabloid, dan majalah yang tercetak; juga bisa diulang-ulang penyiarannya sesuai kebutuhan. Alhasil, pelipatgandaan ini menimbulkan dampak yang sangat besar di tengah khalayak. Ketiga, setiap media bisa mewacanakan sebuah peristiwa hukum sesuai pandangannya masing-masing, tentu saja dengan fungsi agenda setting yang dimilikinya, media memiliki kesempatan yang sangat luas (bahkan hampir tanpa batas) untuk memberitakan kasus tindak pidana korupsi, sehingga agenda media pararel dengan agenda publik, dan dampaknya akan semakin kuatlah peran media dalam membentuk opini publik.

Tindak pidana korupsi selalu menarik perhatian media massa sebagai bahan liputan. Hal ini terjadi karena adanya 2 (dua) faktor yang saling berkaitan. Pertama, dewasa ini hukum berada di era teknologi informasi dan komunikasi sehingga hampir mustahil bahwa kehidupan hukum itu dipisahkan dari media massa. Konsekuensinya perlu peran aktif dari aparat penegak hukum untuk melibatkan media massa dalam penanggulangan kejahatan termasuk tindak pidana korupsi. Kedua, hukum dalam bentuk tingkah laku dan pernyataan para aktor publik lazimnya selalu mempunyai nilai berita sekalipun peristiwa hukum itu bersifat rutin belaka, seperti pembunuhan, pencurian. Apalagi jika peristiwa hukum itu bersifat luar biasa seperti kejahatan kerah putih dan lain sebagainya.

Liputan peristiwa hukum cendrung lebih rumit ketimbang reportase di bidang kehidupan lainnya. Pada satu pihak, liputan hukum memiliki dimensi pembentukan opini publik atau public opinion, baik yang diharapkan oleh para penegak hukum maupun oleh wartawan. Putusan pemidanaan terhadap pelaku tindak pidana korupsi diharapkan mempengaruhi sikap khalayak mengenai perbuatan yang dilakukan oleh terdakwa. Dalam komunikasi politik, aspek pembentukan opini ini memanglah menjadi suatu tujuan utama, karena hal ini akan mempengaruhi pencapaian-pencapaian tujuan pidana.

\section{Fungsi dan juga Peranan Media Massa untuk Menciptakan Budaya Malu Pelaku Tindak Pidana Korupsi}

Sejatinya untuk bangsa Indonesia, budaya malu ini merupakan akar masyarakat yang mempunyai basis sosial yang mana cukup kuat. Hal ini ditandai dengan adanya berbagai icon yang merepresentasikan kultur masyarakat bangsa Indonesia. Seperti adanya istilah budaya timur, adat jawa, dan lain sebagainya, yang mencerminkan kebersehajaan, dan kolektivitas model kultur yang dianut masyarakat bangsa Indonesia.

Secara garis besar budaya dunia ini terbagi menjadi 2 (dua), budaya individualis (Eropa dan Amerika Utara) dan budaya kolektivitas (Asia, Afrika, Amerika Selatan, dan Kepulauan Pasifik) yang masing-masing mempunyai varian-variannya. Meskipun terdapat banyak pola dalam masyarakat kolektivitas, terdapat kesamaan dalam pola-pola tersebut. Di suatu Negara boleh jadi terdapat kecenderungan individualis dan kecenderungan kolektivitas, tanpa harus bertentangan. Namun salah satunya cendrung mendominasi. Di Indonesia yang lebih dominan adalah kolektivitas (Deddy Mulyana, 2008:61-62).

Pada lazimnya dalam masyarakat kolektivitas, diri atau self tidak bersifat unik atau otonom, melainkan lebur dalam kelompok (keluarga, klan, kelompk kerja, suku bangsa, dan sebagainya). Karena itu perilaku individu sangat dipengaruhi kelompoknya dan tidak dianjurkan untuk menonjol sendiri. Keberhasilan individu adalah keberhasilan kelompok dan kegagalan individu juga adalah kegagalan kelompok. Maka, bilamana seseorang telah melakukan suatu perbuatan membanggakan, maka banggalah pada kelompoknya, dan juga sebaliknya bila melakukan kecurangan. 
Menurut Deddy Mulyana, masyarakat bangsa Indonesia yang bersifat kolektivitas tampak gambling ketika puluhan orang mengantarkan atau menjemput setiap anggota keluarga atau kerabat mereka yang menunaikan ibadah haji. Juga dalam pesta perkawinan yang mana dihadiri ratusan hingga ribuan orang, yang membuat orang-orang dari budaya individualis merasa heran. Dalam masyarakat kolektivitas, individu terkait oleh lebih sedikit kelompok, namun pada keterikatan tersebut lebih kuat dan lebih lama. Selain itu hubungan bersifat total, sekaligus di lingkungan domestik dan ruang publik. Karena identifikasi yang kuat dengan kelompok, manusia kolektivitas sangat peduli dengan peristiwa-peristiwa yang menyangkut kelompoknya (Deddy Mulyana, 2008:62)

Budaya kolektivitas sebagaimana telah penulis deskripsikan di atas, dalam teori komunikasi dapat dimanfaatkan untuk dapat membangun akan adanya kesadaran bersama dalam berinteraksi sosial untuk mencapai suatu tujuan tertentu.

Hal ini didasarkan atas suatu pemikiran, dalam masyarakat kolektivitas, media massa dan media lainnya yang digunakan individu (telepon, e-mail) merupakan penunjang komunikasi manusia yang turut menyuburkan berita (informasi). Media sering menggunakan penjulukan terhadap seseorang yang diberitakan. Penjulukan atau labeling menurut Deddy Mulyana akan menimbulkan nubuat yang dipenuhi sendiri atau self-fulfilling prophecy (Deddy Mulyana, 2008:65)

Dari pendapat di atas, tampak diketahui bahwa penjulukan atau juga labeling merupakan dampak pemberitaan media massa. Dalam hal ini penulis mengilustrasikan, jika pejabat A diberitakan telah melakukan tindak korupsi, maka secara tidak langsung media telah membentuk opini pada masyarakat bahwa pejabat A tersebut koruptor, sehingga apa pun yang dikatakan atau dilakukan orang yang bersangkutan akan diinterpretasikan berdasarkan perjulukan atau labeling sebagai koruptor. Orang yang bersangkutan menjadi sulit untuk membela diri dan menghindar dari tuduhan tersebut.

Menurut Deddy Mulyana, bahwa teori penjulukan atau labeling diilhami terutama oleh teori interaksi simbolik. Menurut teori interkasi simbolik, seorang manusia belajar untuk memainkan berbagai peran dan mengasumsikan identitas yang relevan dengan peran-peran ini, dapat menunjukkan kepada satu sama lainnya siapa dan apa mereka, serta mendefinisikan situasi-situasi yang mereka masuki, dan perilaku pun berlangsung di konteks identitas sosial, makna dan definisi situasi itu (Deddy Mulyana, 2008:66).
Teori penjulukan atau juga disebut dengan istilah labeling menganggap penyimpangan atau deviance bukan sebagai seperangkat karakteristik individu atau kelompok, melainkan sebagai suatu proses interaksi antara deviants dan juga non-deviants. Mereka yang merepresentasikan kekuasaan (sebagai atasan, orang yang berstatus lebih tinggi, suami, dan sebagainya) atau yang mampu memaksakan definisi moralitas konvensional terhadap orang lain, akan menyediakan sumber utama penjulukan. Julukan-julukan yang diterapkan supaya menciptakan kategori-kategori penyimpangan dan dengan demikian mencerminkan struktur kekuasaan masyarakat.

Berdasarkan diskursus mengenai teori labeling dari perspektif teori komunikasi di atas, maka dapat diketahui bahwasanya teori labelling atau penjulukan mempunyai peran penting dalam aspek pencegahan dan penanggulangan kriminal (khususnya tindak pidana korupsi). Peranan teori ini berangkat dari asumsi bahwa tidak ada suatu tindakan pun yang secara intrinsik kriminal. Artinya, seseorang diberi cap atau label penjahat terlebih dahulu ditetapkan oleh sistem peradilan pidana. Proses pemberian label terhadap seseorang sebagai koruptor akan memberi dampak yang dahsyat terhadap citra diri seseorang. Dampak penjulukan atau labeling ini lebih hebat juga bila disebarkan oleh pers atau media massa, karena media massa mempunyai keunggulan-keunggulan yang lebih luas menginformasikan sesuatu hal kepada publik (masyarakat).

Dalam teori labeling tampak pula diketahui bahwa labeling ini merupakan problematika. Dikatakan oleh Deddy Mulyana prosesnya seperti lingkaran setan (Deddy Mulyana, 2008:66). Problematika di dalam teori labeling ini mengingat cap atau label yang mana melekat pada seseorang telah diyakini dan dianggap mempunyai nilai kebenaran dalam persepsi masyarakat.

Dilihat dari sisi teori labeling maka sangat sulit mengubah keadaan atau konsekuensi atas penjulukan tersebut, karena persepsi masyarakat telah terbangun oleh penyebaran informasi yang disampaikan melalui media massa. Dalam teori komuniksi, problematika ini disebut dengan sifat irreversible. Artinya, sekali pesan termasuk penjulukan disampaikan kepada khalayak pemerisa, maka amatlah sulit bagi siapa pun untuk meniadakan sama sekali efeknya (Deddy Mulyana, 2008:37). Jika seseorang diberitakan secara negatif, maka pemberitaan itu sulit untuk mengembalikan citra si seseorang ke semula.

Deddy Mulyana mencontohkan pengalaman pahit yang dialami Washington Post di Amerika Serikat. 
Surat kabar Washington Post pernah memuat berita sensasional yang cukup buruk tentang seorang tokoh. Diketahui kemudian bahwa berita itu tidak benar. Sesuai dengan norma yang berlaku, maka sang tokoh diberi hak jawab, namun bantahannya tidak berhasil menghapus kesan buruk yang telah terlanjur menyebar dan tertanam di kalangan masyarakat karena berita yang bohong tersebut. Sang tokoh kemudian bangkrut, putus asa, dan melakukan bunuh diri (Kompas, 10 Oktober 1997:6-7).

Berdasarkan pada pandangan atau juga pendapat dari para narasumber di atas dapatlah disimpulkan bahwa apabila media massa dimanfaatkan oleh para penegak hukum dalam peradilan tindak pidana korupsi untuk memberitakan atau menginformasikan kepada masyarakat tentang pengungkapan kasus korupsi yang sedang ditanganinya, maka hal ini akan berdampak pula pada suatu pengembangan pandangan-pandangan masyarakat tentang nilai-nilai moral yang baik antara lain penguatan budaya malu di kalangan masyarakat. Sehingga dengan adanya budaya malu ini dapatlah mencegah bagi pelaku potensial melakukan tindak pidana korupsi, dan juga bagi pelaku aktual maupun keluarganya akan menimbulkan efek jera sehingga tidak akan mengulangi tindak pidana korupsi tersebut di masa mendatang.

Dilihat dari teori media massa, dampak materi pemberitaan untuk menciptakan budaya malu dalam tindak korupsi ini dikenal dengan teori stimulusrespons (S-R theory). Teori ini dikenal juga dengan istilah teori jarum hipodermik (hypodermic needle theory) atau teori peluru ajaib (magic bullet theory). Disebut demikian karena teori ini meyakini bahwa kegiatan mengirimkan pesan sama halnya dengan tindakan menyuntikkan obat yang bisa langsung masuk ke dalam jiwa penerima pesan, sebagaimana peluru yang ditembakkan dan langsung masuk ke dalam tubuh (Morissan, 2007:17).

\section{Pelaksanaan dan Pemanfaatan Media Massa oleh Penegak Hukum (Kepolisian, Kejaksaan, KPK, Pengadilan, dan Lembaga Pemasyarakatan)}

Berdasarkan keterangan dari para narasumber penelitian ini, dapat diketahui bahwa pelaksanaan pemanfaatan dari pihak media massa oleh penegak hukum (Kepolisian, Kejaksaan, KPK, Pengadilan dan Pemasyarakatan) dalam menangani permasalahan tindak pidana korupsi, pada dasarnya media massa sudah dimanfaatkan oleh para aparat penegak hukum untuk memberitakan berbagai kasus korupsi yang sedang ditanganinya. Namun pemanfaatan media massa oleh para penegak hukum itu menurut hemat penulis berdasarkan keterangan dari para wartawan yang menjadi narasumber penelitian, masih bersifat pasif kecuali pemanfaatan dari media massa yang dilakukan oleh pihak KPK. Artinya bahwa pihak penegak hukum (kepolisian, kejaksaan, pengadilan, pemasyarakatan) tidak secara proaktif memberikan berita tentang penanganan kasus korupsi kepada media massa, namun mereka tergantung pada pihak wartawan media massa yang mencari berita tentang kasus korupsi tersebut.

Untuk memahami pelaksanaan pemanfaatan media massa media massa oleh penegak hukum (Kepolisian, Kejaksaan, KPK, Pengadilan dan Pemasyarakatan) dalam menangani tindak pidana korupsi, dapat pula dijelaskan dengan menggunakan teori bekerjanya hukum yang dikemukakan Robert B. Seidman yang digambarkan dengan skema sebagai berikut:

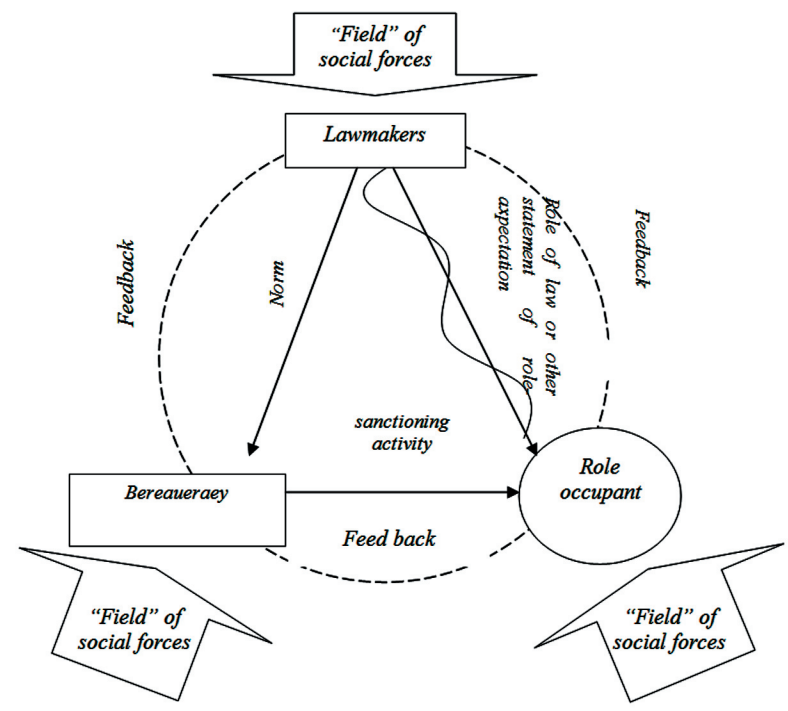

This model can be restated in a set of propositions:

1. Every rule of law prescribes how a role occupant is expected to act.

2. How a role occupant will act in response to norms of law is a function of the rules laid down, their sanctions, the activity of enforcement institutions, and the entire complex of social, political, and other forces affecting him.

3. How the enforcement institutions will act in response to norms of law is a function the rules laid down, their sanctions, the entire complex of social, political, and other forces affecting it, and the feedbacks from role occupants.

4. How the lawmakers will act is a function of the rules laid down for their behavior their sanctions, the entire complex of social, political, ideological, and other forces affecting them, and the feedbacks from role occupants and bureaucracy (Robert B. Seidman, 1972:32)

Preposisi seperti ditulis oleh Robert B. Siedman tersebut, yang mana oleh Satjipto Rahardjo kemudian diterjemahkan sebagai berikut: 
1. Setiap peraturan hukum memberitahu tentang bagaimana seseorang pemegang peran atau role occupant itu diharapkan bertindak.

2. Bagaimana seorang pemegang peran akan bertindak sebagai respon terhadap peraturan-peraturan hukum itu, merupakan fungsi dari peraturan-peraturan yang ditujukan kepadanya, sanksi-sanksinya, aktivitas dari lembaga-lembaga pelaksana serta keseluruhan kompleks kekuatan sosial, politik dan lainnya mengenai dirinya.

3. Bagaimana lembaga-lembaga pelaksana itu akan bertindak sebagai respon terhadap peraturan hukum merupakan fungsi peraturan-peraturan hukum yang ditujukan kepada mereka, sanksi-sanksinya keseluruhan kompleks kekuatan-kekuatan sosial, politik dan lainnya yang mengenai diri mereka serta umpan-umpan balik yang datang dari para pemegang peran.

4. Bagaimana para pembuat undang-undang itu akan bertindak merupakan fungsi peraturan-peraturan yang mengatur tingkah laku mereka, sanksi-sanksinya, keseluruhan kompleks kekuatan-kekuatan sosial, politik, ideologis dan lain-lainnya yang mengenai diri mereka serta umpan-umpan balik yang datang dari pemegang peran serta birokrasi (Satjipto Rahardjo, 1980:27).

Salah satu preposisi yang berhubungan dengan pembahasan tentang pelaksanaan pemanfaatan media massa oleh penegak hukum dalam menangani tindak pidana korupsi adalah preposisi yang ketiga yang dinyatakan, bagaimana lembaga-lembaga pelaksana itu akan bertindak sebagai respon terhadap peraturan hukum merupakan fungsi peraturan-peraturan hukum yang ditujukan kepada mereka, sanksi-sanksinya keseluruhan kompleks kekuatan-kekuatan sosial, politik dan lainnya yang mengenai diri mereka serta umpan-umpan balik yang datang dari para pemegang peran. Dengan demikian preposisi tersebut dengan kata lain dapat dikemukakan bahwasanya lembaga pelaksana dalam hal ini adalah lembaga penegak hukum (Kepolisian, Kejaksaan, KPK, Pengadilan dan Pemasyarakatan) akan bertindak sebagai respon terhadap peraturan hukum yang ditujukan kepada mereka, sanksi-sanksinya dan keseluruhan kompleks kekuatan-kekuatan sosial, politik dan lainnya yang mengenai diri mereka serta umpan-umpan balik yang datang dari para pemegang peran.

Berdasarkan pada preposisi tersebut, maka apabila dihubungkan dengan data yang telah diperoleh dalam hal pelaksanaan pemanfaatan dari media massa oleh penegak hukum (Kepolisian, Kejaksaan, Pengadilan juga Pemasyarakatan) dalam menangani tindak pidana korupsi, maka pemanfaatan media massa yang masih bersifat pasif oleh Kepolisian, Kejaksaan, Pengadilan dan Pemasyarakatan dipengaruhi antara lain faktor hukum. Dalam hal ini karena belum ada hukum yang mengatur tentang kewajiban penegak hukum tersebut untuk menginformasikan mengenai tindak pidana korupsi yang ditanganinya kepada masyarakat melalui media massa. Sehingga karena belum ada peraturan hukum yang memerintahkan penegak hukum tersebut untuk kemudian memanfaatkan media massa dalam menginformasikan kepada publik mengenai tindak pidana yang ditanganinya, maka mereka merasa tidak perlu dan tidak wajib untuk secara aktif memantaatkan media massa untuk menginformasikan kepada publik tentang perkara tindak pidana korupsi dimaksud. Belum adanya peraturan ini dapat jadi umpan balik atau feedback bagi pembuat undang-undang untuk merumuskan ketentuan hukum yang memerintahkan penegak hukum pidana untuk memberikan informasi kepada publik dalam menangani perkara tindak pidana korupsi dengan memanfaatkan media massa.

\section{Implementasi Pemanfaatan Media Massa dalam Pembaharuan Kebijakan Formulasi dari Sistem Peradilan Pidana Korupsi di Indonesia}

Dilihat dari aspek kebijakan, sistem peradilan pidana terhadap tindak pidana korupsi di Indonesia mencakup hukum pidana materiil dan hukum pidana formiil. Hal ini menandakan bila tindak pidana korupsi merupakan tindak pidana khusus yang pengaturannya terdapat di luar Kitab Undang-Undang Hukum Pidana (KUHP).

Pengaturan yang mana berkaitan dengan sistem peradilan pidana korupsi dapatlah dijumpai dalam beberapa Undang-Undang sebagai berikut: 1. UndangUndang No. 28 Tahun 1999 tentang Penyelenggara Negara yang Bersih dan Bebas dari Korupsi, Kolusi dan Nepotisme; 2. Undang-Undang No. 31 Tahun 1999 tentang Pemberantasan Tindak Pidana Korupsi sebagaimana telah diubah dengan Undang-Undang No. 20 Tahun 2001 tentang Perubahan atas UndangUndang Negara Republik Indonesia No. 31 Tahun 1999 tentang Pemberantasan Tindak Pidana Korupsi; 3. Undang-Undang No. 46 Tahun 2009 mengenai Pengadilan Tindak Pidana Korupsi (Tipikor); dan 4. Undang-Undang No. 30 Tahun 2002 tentang Komisi Pemberantasan Tindak Pidana Korupsi (KPK);

Dari keempat peraturan yang berkaitan dengan penanganan akan tindak pidana korupsi di atas itu hanya ada satu undang-undang yang mengisyaratkan pengaturan tentang pemanfaatan media massa, yaitu dalam Undang-Undang No. 46 Tahun 2009 tentang Pengadilan Tindak Pidana Korupsi (Tipikor). Ada salah satu pasal dalam Undang-Undang Pegadilan Tipikor tersebut yang secara implisit mengatur tentang transparansi dan akuntabilitas kinerja Pengadilan Tipikor yaitu diatur dalam Bab V tentang Transparansi dan Akuntabilitas, Pasal 24 yang merumuskan: 1. Setiap orang berhak untuk memperoleh informasi 
dari Pengadilan Tindak Pidana Korupsi sesuai dengan dengan ketentuan peraturan perundang-undangan; 2. Pengadilan Tindak Pidana Korupsi menyediakan informasi yang bersifat terbuka dan dapat diakses oleh publik mengenai penyelenggaraan Pengadilan Tindak Pidana Korupsi; 3. Ketentuan lebih lanjut mengenai hak dan informasi yang bersifat terbuka diatur dengan Peraturan Mahkamah Agung.

Ketentuan Pasal 24 Undang-Undang Pengadilan Tipikor di atas, pada pokoknya memberikan hak kepada setiap orang yang mana telah disediakan oleh Pengadilan Tipikor termasuk media massa untuk memperoleh informasi dan dapat diakses oleh publik mengenai penyelenggaraan Pengadilan Tipikor.

Ketentuan Pasal 24 Undang-Undang Pengadilan Tipikor tersebut memberi kesempatan kepada publik termasuk dalam media massa secara aktif mengakses informasi yang diberikan oleh Pengadilan Tipikor. Maka dengan demikian apabila media massa secara rutin dan juga terus-menerus mengakses informasi yang disediakan oleh Pengadilan Tipikor tentang Penyelenggaraan Pengadilan Tipikor, maka media massa telah melaksanakan fungsinya sebagai media informasi dan media kontrol sosial, dan sekaligus dapat melaksanakan peranannya dalam melakukan pengawasan, kritik, koreksi dan juga saran terhadap penyelenggaraan Pengadilan Tipikor serta mendorong terwujudnya supremasi hukum dalam penegakan hukum tindak pidana korupsi. Di samping itu dengan memberitakan penyelenggaraan Pengadilan Tipikor, maka media massa berarti juga telah melaksanakan peranannya dalam mengembangkan pendapat umum bahwa perbuatan korupsi merupakan perbuatan yang tercela, melawan hukum dan dapat merusak sendisendi moral masyarakat dan pemerintahan.

Pentingnya pengaturan tentang transparansi dalam pemberantasan korupsi dan pentingnya pemanfaatan peran media massa secara optimal untuk mendorong pengawasan terhadap upaya pemberantasan korupsi, antara lain yang diungkapkan oleh Daniel Kaufmann, Direktur Programs World Bank Institute seperti uraian berikut ini:

Daniel Kaufmann, Direktur Programs World Bank Institute, mengungkapkan setidaknya dalam empat tahun terakhir berdasarkan indek prestasi korupsi yang disusun Transparancy International Indonesia berada dalam kelompok 10 negara terkorup di dunia, padahal berbagai upaya sudah dilakukan untuk memberantas korupsi. Pemerintah Indonesia telah dapat melakukan banyak hal, misalnya telah membentuk KPK dan Tim Koordinasi Pemberantasan Tindak Pidana Korupsi. Bahkan bila pada masa lalu pejabat mustahil mejadi tersangka perkara korupsi, kini sejumlah bupati dan gubernur sudah menjadi tersangka, bahkan terpidana perkara korupsi (http/antikorupsi.ong/indo/consent/ view/8007/6/).

Menurut Kaufmann Indonesia melakukan banyak hal baik untuk mengontrol korupsi, mendobrak hal-hal di masa lalu untuk menyelesaikan perkara korupsi. Kepemimpinan sekarang yang penuh integritas tanpa skandal adalah kredit yang lebih baik bagi Indonesia. Namun yang perlu ditingkatkan adalah transparansi dalam pemberantasan korupsi. Optimalkan peran media massa untuk mendorong pengawasan terhadap upaya pemberantasan korupsi. Kualitas peraturan pada tahun 2002 berada pada tingkatan 16 terbawah dari 202 negara dalam hal mengontrol korupsi. Pada tahun 2004 Indonesia berada pada urutan 40 terbawah dari 204 negara. Jadi sebenarnya tidak bisa dikatakan bahwa Indonesia tidak melakukan sesuatu karena Indonesia semakin baik dalam beberapa tahun ini.

Dalam peraturan perundang-undangan Indonesia dewasa ini, secara yuridis sudah terdapat adanya dukungan terhadap pemanfaatan media massa dalam rangka pemberantasan tindak pidana korupsi. Hal ini seperti diatur dalam Undang-Undang No. 40 Tahun 1999 mengenai Pers dan Undang-Undang No. 14 Tahun 2008 tentang Keterbukaan Informasi Publik serta Undang-Undang No. 46 Tahun 2009 tentang Pengadilan Tindak Pidana Korupsi.

Dengan adanya dukungan secara yuridis baik dari Undang-Undang Pers maupun Undang-Undang Keterbukaan Informasi Publik sebagaimana telah disebutkan di atas, dan telah diawali pula dengan adanya pengaturan tentang transparansi dan juga akuntabilitas kinerja dari pengadilan tindak pidana korupsi sebagaimana yang di atur di dalam Pasal 24 Undang-Undang No. 46 Tahun 2009 mengenai Pengadilan Tindak Pidana Korupsi, maka dewasa ini perlu ada political will dari pemerintah untuk mengimplementasikan pemanfaatan media massa dalam pembaharuan kebijakan formulasi peraturan perundang-undangan sistem peradilan pidana korupsi, terutama dalam undang-undang sebagaimana berikut: 1. Undang-Undang No. 28 Tahun 1999 mengenai Penyelenggara Negara Yang Bersih dan juga Bebas dari Korupsi, Kolusi dan Nepotisme; 2. UndangUndang No. 31 Tahun 1999 tentang Pemberantasan Tindak Pidana Korupsi sebagaimana telah diubah dengan adanya Undang-Undang No. 20 Tahun 2001 tentang Perubahan atas Undang-Undang Republik Indonesia No. 31 Tahun 1999 tentang Pemberantasan Tindak Pidana Korupsi; 3. Undang-Undang No. 30 Tahun 2002 tentang Komisi Pemberantasan Tindak 
Pidana Korupsi; 4. Undang-Undang No. 46 Tahun 2009 tentang Pengadilan Tindak Pidana Korupsi (Tipikor); 5. Undang-Undang No. 12 Tahun 1995 tentang Pemasyarakatan.

Bentuk implementasi pemanfaatan media massa berupa pembaharuan kebijakan formulasi kedalam kelima undang-undang yang tersebut di atas, dengan perumusan sebagai berikut:

Pertama, Undang-Undang No. 28 Tahun 1999 tentang Penyelenggara Negara yang Bersih dan Bebas dari Korupsi, Kolusi dan Nepotisme: Dalam UndangUndang ini perlu ditambahkan ketentuan tentang transparansi dan akuntabilitas dengan memanfaatkan media massa bagi penegak hukum yang menangani tindak pidana yang diatur dalam Undang-Undang No. 28 Tahun 1999 tersebut. Adapun perumusan ketentuan dimaksud adalah seperti berikut ini: 1. Dalam proses penyidikan, penuntutan, dan pemeriksaan di sidang pengadilan serta pelaksanaan pidana dalam perkara tindak pidana kolusi dan juga nepotisme, penegak hukum pada masing-masing proses tersebut wajib menyediakan informasi yang bersifat terbuka dan dapat diakses oleh publik mengenai penyelenggaraan penyidikan, penuntutan, dan pemeriksaan di sidang pengadilan serta pelaksanaan pidana; 2 . Informasi yang mana telah disediakan oleh lembaga penegak hukum dalam proses penyidikan, penuntutan, dan pemeriksaan di sidang pengadilan serta pelaksanaan pidana tersebut wajib pula diberikan kepada media massa untuk dipublikasikan.

Kedua, pada Undang-Undang No. 31 Tahun 1999 Pemberantasan Tindak Pidana Korupsi Sebagaimana telah diubah dengan Undang-undang No. 20 Tahun 2001 tentang Perubahan atas Undang-Undang Negara Republik Indonesia No. 31 Tahun 1999 mengenai Pemberantasan Tindak Pidana Korupsi. Di dalam undang-undang ini perlulah ditambahkan ketentuan mengenai transparansi dan juga akuntabilitas dengan memanfaatkan media massa bagi penegak hukum yang menangani tindak pidana korupsi yang diatur dalam Undang-Undang No. 31 Tahun 1999 tentang Pemberantasan Tindak Pidana Korupsi sebagaimana telah diubah dengan Undang-undang No. 20 Tahun 2001 tentang Perubahan atas Undang-undang Negara Republik Indonesia No. 31 Tahun 1999 mengenai Pemberantasan Tindak Pidana Korupsi. Perumusan ketentuan dimaksud adalah seperti ini: 1. Dalam proses penyidikan, penuntutan, dan pemeriksaan di sidang pengadilan serta pelaksanaan pidana dalam perkara tindak pidana korupsi, penegak hukum pada masing-masing proses tersebut wajib menyediakan informasi yang bersifat terbuka dan dapat diakses oleh publik mengenai penyelenggaraan penyidikan, penuntutan, dan pemeriksaan di sidang pengadilan serta pelaksanaan pidana; 2. Informasi yang telah disediakan oleh lembaga penegak hukum di dalam proses penyidikan, penuntutan, dan pemeriksaan di sidang pengadilan serta pelaksanaan pidana tersebut wajib pula diberikan kepada media massa untuk dipublikasikan; 3. Undang-Undang No. 30 Tahun 2002 tentang Komisi Pemberantasan Tindak Pidana Korupsi (KPK).

Dalam undang-undang ini perlu ditambahkan akan ketentuan tentang transparansi dan akuntabilitas dengan memanfaatkan media massa bagi Komisi Pemberantasan tindak Korupsi atau KPK pada saat menangani tindak pidana korupsi. Sehingga dalam Undang-Undang No. 30 Tahun 2002 tentang Komisi Pemberantasan Tindak Pidana Korupsi tersebut perlu ditambah perumusan seperti berikut ini: 1. Dalam proses penyidikan dan penuntutan tindak pidana korupsi, Komisi Peberantasan Korupsi ini wajib untuk menyediakan informasi yang bersifat terbuka dan dapat diakses oleh publik mengenai penyelenggaraan penyidikan, dan penuntutan dimaksud; 2. Informasi yang telah disediakan oleh Komisi Pemberantasan Korupsi tentang proses penyidikan dan penuntutan perkara tindak pidana tersebut wajib pula diberikan kepada media massa untuk dipublikasikan.

Ketiga, pada Undang-Undang No. 46 Tahun 2009 tentang Pengadilan Tindak Pidana Korupsi (Tipikor). Ketentuan yang diatur Pasal 24 tentang transparansi dan akuntabilitas itu perlu ditambahkan satu ayat seperti berikut ini, informasi yang telah disediakan oleh Komisi Pemberantasan Korupsi tentang proses penyidikan dan penuntutan perkara tindak pidana korupsi tersebut wajib pula diberikan kepada media massa untuk dipublikasikan.

Keempat, Undang-Undang No. 12 Tahun 1995 tentang Pemasyarakatan. Dalam undang-undang ini perlu ditambahkan ketentuan tentang transparansi dan akuntabilitas dengan memanfaatkan media massa bagi penegak hukum yang menangani pelaksanan putusan pidana perampasan kemerdekaan (pidana penjara dan/atau kurungan) dalam tindak pidana korupsi. Sehingga dalam Undang-Undang No. 12 Tahun 1995 tentang Pemasyarakatan tersebut perlu ditambah perumusan seperti berikut ini: 1. Dalam proses pelaksanaan putusan pidana akan perampasan kemerdekaan (pidana penjara dan/atau kurungan) di dalam suatu perkara tindak pidana korupsi, Lembaga Pemasyarakatan atau Balai Pemasyarakatan wajib menyediakan informasi yang bersifat terbuka dan dapat diakses oleh publik mengenai penyelenggaraan 
penempatan dan pembinaan narapidana kasus korupsi; 2. Informasi yang telah disediakan oleh Lembaga Pemasyarakatan dan Balai Pemasyarakatan tersebut wajib pula diberikan kepada media massa untuk dipublikasikan.

Tujuan dalam diaturnya ketentuan tersebut di atas adalah untuk lebih meningkatkan fungsi pengawasan atau juga kontrol sosial terhadap kinerja lembaga penegak hukum dalam menangani perkara tindak pidana korupsi, sehingga setiap instansi penegak hukum tersebut akan bekerja secara optimal dan profesional.

Dengan perkatan lain dapat dikemukakan pula bahwa dengan adanya pengaturan kewajiban bagi penegak hukum untuk menginformasikan kepada masyarakat melalui media massa mengenai kasus korupsi yang sedang ditangani, maka hal ini akan meningkatkan peran kontrol sosial dari masyarakat terhadap penanganan kasus korupsi. Dengan adanya kontrol atau pengawasan dari masyarakat terhadap penegakan hukum terhadap kasus korupsi tersebut, maka penegak hukum akan bekerja lebih hati-hati dan bersungguh-sungguh serta transparan. Sehingga hal ini tentunya akan meningkatkan kinerja penegak hukum untuk bekerja secara optimal dan profesional. Pada akhirnya penegakan hukum kasus tindak pidana korupsi akan berjalan secara tepat dan benar, sehingga dapat menunjang penegakan hukum pidana secara lebih efektif.

\section{PENUTUP \\ Kesimpulan}

Fungsi dan juga peranan media massa di dalam upaya penanggulangan tindak pidana korupsi dapat dikemukakan sebagai berikut: 1 . Fungsi dan peran media massa dalam penanggulangan tindak pidana korupsi adalah berperan sebagai alat kontrol yaitu dengan melakukan pengawasan, kritik, koreksi dan saran, serta mendorong untuk mewujudkan supremasi hukum, sehingga dampak positif daripada fungsi ini adalah penegak hukum (sistem peradilan pidana) akan dapat mengoptimalkan pelaksanaan penanganan tindak pidana korupsi; 2. Fungsi informasi media massa yang mempunyai efek kognitif (pengetahuan), afektif (perasaan) dan konatif. Efek kognitif meliputi peningkatan akan kesadaran, belajar, dan tambahan akan pengetahuan. Efek afektif berhubungan dengan emosi, perasaan, dan attitude atau sikap. Sedangkan efek konatif berhubungan dengan perilaku dan niat untuk melakukan sesuatu menurut cara yang tertentu. Fungsi informasi melalui pemberitaan media massa tentang kasus-kasus korupsi dapat memberikan efek kognitif, afektif dan konatif bagi masyarakat sehingga dapat meningkatakan peran pengawasan masyarakat atau kontrol sosial bagi bekerjanya penegak hukum dalam menangani kasus tindak pidana korupsi.

Pelaksanaan pemanfaatan dari pihak media massa oleh penegak hukum (Kepolisian, Kejaksaan, KPK, Pengadilan dan Pemasyarakatan) dalam menangani tindak pidana korupsi dapat dikemukakan sebagai berikut: 1 . Pemanfaatan media massa oleh kepolisian, kejaksaan dan pengadilan serta pemasyarakatan dalam penanganan kasus korupsi belum optimal dan masih bersifat pasif, artinya informasi bahan berita yang diterima media massa sebagian besar merupakan hasil usaha yang proaktif dari media massa dalam mencari dan mendapatkan berita tentang penanganan korupsi oleh penegak hukum dimaksud; 2. Pemanfaatan secara aktif media massa dalam penanganan tindak pidana korupsi hanya dilakukan oleh aparat penegak hukum Komisi Pemberantasan Korupsi yang diwujudkan dalam berbagai bentuk kerjasama antara KPK dengan pihak media massa, misalnya kerjasama KPK dengan media massa Jawa Pos.

Implementasi pemanfaatan media massa dalam pembaharuan kebijakan formulasi sistem peradilan pidana korupsi yaitu perlulah dirumuskan dalam peraturan perundang-undangan hukum acara peradilan pidana korupsi dan hukum pelaksanaan pidana korupsi yang memuat ketentuan dalam penanggulangan tindak pidana korupsi.

\section{Rekomendasi}

Perlulah dioptimalkan fungsi bagian hubungan masyarakat atau humas pada masing-masing lembaga penegak hukum (kepolisian, kejaksaan, pengadilan dan pemasyarakatan) untuk menginformasikan kepada masyarakat melalui media massa tentang kasus yang sedang ditanganinya.

Perlu diciptakan persamaan persepsi penegak hukum dalam sistem peradilan pidana korupsi tentang pentingnya pemanfaatan media massa dalam rangka mewujudkan penanggulangan tindak pidana korupsi yang efektif.

Perlulah dilakukan pembaharuan dalam hukum acara dan hukum pelaksanaan pidana dalam proses peradilan pidana korupsi yang mengatur pemanfaatan media massa dalam rangka penanggulangan tindak pidana korupsi di Indonesia.

Pemanfaatan media massa dalam pembaharuan hukum acara pidana dan juga hukum pelaksanaan pidana dalam sistem peradilan tindak pidana korupsi: Dalam menangani suatu kasus tindak pidana korupsi, aparat penegak hukum sejak pada tingkat penyidikan, 
penuntutan dan pemeriksaan sidang pengadilan wajib menginformasikan kepada masyarakat baik melalui media massa cetak maupun elektronik yang disampaikan melalui bagian hubungan masyarakat atau humas atau pusat penerangan masyarakat yang ada pada masing lembaga penegak hukum tersebut.

Formulasi akan pemanfaatan media massa dalam hukum pelaksanaan pidana pencabutan kemerdekaan. Kepala Lembaga Pemasyarakatan atau Kepala Balai Pemasyarakatan yang membina narapidana korupsi, wajib untuk menginformasikan kepada masyarakat melalui media massa baik media cetak ataupun yang elektronik, sehubungan dengan kegiatan pembinaan dan penempatan narapidana korupsi di Lembaga Pemasyarakatan dan pembinaan narapidana korupsi di luar Lembaga Pemasyarakatan karena mendapatkan pembebasan bersyarat, cuti menjelang bebas, cuti bersyarat.

\section{DAFTAR PUSTAKA}

\section{Buku:}

Arief, Barda Nawawi, 1996, Bunga Rampai Kebijakan Hukum Pidana, Bandung: Citra Aditya Bakti.

Hamzah, Andi, 1991, Korupsi Indonesia Masalah dan Pemecahannya, Jakarta: Gramedia Pustaka Utama.

Isra, Saldi, 2005, Peran Pers dalam Pemberantasan Korupsi: Makalah disampaikan dalam Pelatihan Jurnalistik dan Wawasan jajaran Harian Umum Lampung Post, di Hotel Papandayan Bandung, 18-21 Juli 2005.
Morissan, 2004, Jurnalistik Televisi Mutakhir, (Risman F. Sikumbangk, Ed.), Ciawi-Bogor Selatan: Ghalia Indonesia.

Mulyana, Deddy, 2008, Komunikasi Massa Kontroversi, Teori, dan Aplikasi, Bandung: Widya Padjadjaran.

Peter, Hoefnagels G., 1969, The Other Side of Criminology. An Inversion of the Concept of Crime, Kluwer-Deventer: Professor of Criminologi Roterdam University.

Rahardjo, Satjipto, 1980, Hukum dan Masyarakat, Bandung: Angkasa.

Seidman, Robert B., 1972, Law and development: A General Model dalam Law and society review, Jilid VII, Madison: University of Wisconsin.

Wahidin, Samsul, 2006, Hukum Pers, Yogyakarta: Pustaka Pelajar.

\section{Surat Kabar:}

Kompas, 10 Oktober 1997.

Suara Merdeka, 13 Januari 2010.

Suara Merdeka, 13 Desember 2010.

\section{Internet:}

Mangkoesapoetra, Arief A., 2010, Pemanfaatan Media Massa Sebagai Sumber Pembelajaran IPS di Tingkat Persekolahan, http://researchengines.com/mangkoes6-04-2.html diakses tanggal 31 Agustus 2010.

http/antikorupsi.ong/indo/consent/view/8007/6/

www.subscrib.com diakses tanggal 9 Oktober 2010 